PEDAGÓGUSKÉPZÉS, 10-11 (39-40), 2012-2013. 207-209.

\title{
GYERMEKSORSOK, ÉLETUTAK A JAVÍTÓINTÉZETI VILÁGBÓL
}

\author{
BERÉNYI ILDIKó \\ az Eötvös Loránd Tudományegyetem Pedagógiai és Pszichológiai Kar \\ Neveléstudományi Doktori Iskolájának \\ hallgatója \\ berenyi.ildiko@gmail.com
}

A közelmúltban figyelemre méltó szakkönyv jelent meg Hegedüs Judittól, aki több éve foglalkozik a gyermek- és fiatalkorúak kriminalizálódásával. A kötetet pedagógusoknak, szociológusoknak, szociális területen tevékenykedőknek ajánlják, de ajánlható mindazoknak, akik érdeklődnek a fiatalkorú bünelkövetés problematikája iránt, vagy szeretnék megismerni a javítóintézetek zárt világát, de azok számára is érdekes olvasmány, akik fogékonyak az új kutatási módszerek megismerésére.

Hegedüs Judit 2004-ben fejezte be doktori tanulmányait, majd 2008-ban védte meg doktori disszertációját, melyet a Fiatalkorú bünelkövetők gyermekkora és a javítóintézetben töltött éveik pedagógiai vizsgálata címmel írt. Az ELTE Pedagógiai és Pszichológiai Intézet Pedagógiatörténeti Tanszékén adjunktus, neveléstörténetet, óvodatörténetet, nevelésszociológiát, gyermek- és ifjúságvédelmet tanít. Az ELTE Tanító- és Óvóképző (Főiskolai) Kar Neveléstudományi Tanszéken óraadó, 2008 őszétől a Rendőrtiszti Főiskolán helyettesítő oktatói feladatot látott el, jelenleg szabadon választható tantárgyat oktat a Nemzeti Közszolgálati Egyetem Rendészettudományi Karán. Az ELTE PPK-n belül müködő Kriminálpedagógiai és Börtönpedagógiai Szakmai Mühely alapítója és a szakmai vezetője. Évek óta rendszeres gyermekvédelmi tanácsadást végez, művészetterápiás foglalkozást tart zárt intézetekben élő fiatalok számára. Számos írása jelent meg a témában: Javitóintézeti neveltek 1945-50 között Aszódon. Budapest, Önkonet, 2005., A javitóintézet világa. Szerkesztett tanulmánykötet. Eötvös József Könyvkiadó, Budapest, 2010.

A recenzált könyv a szerző által végzett kutatást mutatja be, amely az Aszódi és a Rákospalotai Javítóintézetben 2000-ben vette kezdetét és több éves szakmai munka eredményeként született meg. A téma történeti jellegü kutatását kilenc fejezeten keresztül tárgyalja, bevezetve a laikus olvasót is a témába, igaz kicsit hosszasan, viszont az alapos bemutatás hitelesíti a szerzőt, igazolva a témában való jártasságát. Részletesen bemutatja a kutatás során felhasznált elsődleges és másodlagos forrásokat, a történeti és a jelenre vonatkozó kutatás dokumentumait is. Sorra veszi a kriminálstatisztika, környezettanulmányok, élet- és jellemrajzi füzetek, nevelési naplók, jelentések, jegyzőkönyvek, levelek fogalmi magyarázatát példákkal illusztrálva. Megismerhetjük hogyan változott, alakult át hazánkban a büntethetőség életko- 
ri határa a 18. századtól napjainkig, milyen büncselekményeket követtek el a fiatalok, hogyan büntették azt régen és ma. A rendszerváltást követő társadalmi változások a büncselekmények jellegét is átalakították, felvázolja hogyan hatott ez a fiatalkorú bünelkövetőkre, mik az okai napjainkban a fiatalkorúak kriminalizálódásának, miként müködik a pártfogó felügyelet. Bepillantást nyerünk a javítóintézetekben folyó pedagógiai munkába, megismerhetjük hogyan változott a javítóintézeti munka a 19-20. század folyamán, milyen feladatokkal, nehézségekkel kell megküzdeniük a javítóintézeti pedagógusoknak.

A történeti kutatás után következik a könyv kétségkívül legérdekesebb része a pedagógiai etnográfiához sorolható kutatómunka bemutatása négy fejezeten keresztül. A vizsgálódás terepe egy speciális zárt világ, ahol a fiatalok bírósági végzéssel „arra ítéltettek, hogy megnevelődjenek”. Ez az intézmény a Janus-arcú javítóintézet, mely jogintézmény számos büntetőjogi karaktert tartalmaz, viszont müködtet a fiatalok egyéni nevelésének biztosítására terápiás jellegü pedagógiai-pszichológiai eszközöket is. (Hegedüs, 2010, 45. o.) A pedagógiai etnográfia a „nevelést magát a posztmodern felfogás értelmében annak kiszélesedett jelentésében vizsgálja" (Mészáros, 2003, 26. o. idézi Hegedüs). A kutatásban fontos szerepet kapott a terepmunka és a „kutatottakkal” való szoros kapcsolat kialakítása, számos életutat, sorsot smerhetünk meg, amit tematikus csomópontok mentén mutat be a szerző. Az etnográfiai kutatások „,szemléletmódjára jellemző a relatívizmus vagy a bizonyos értelemben vett semlegesség, vagyis a kutatott kultúra értékelés nélküli feltárása, bemutatása; és a részvétel, ami azt jelenti, hogy a kutató a vizsgált kultúrába bekapcsolódva, bizonyos mértékig beépülve vizsgálódik" (Mészáros, 2003, 25. o. idézi Hegedüs).

A kvalitatív kutatási metodológia elméleti hátteréről és jellemzőiről rövid, de körültekintő ismertetést kapunk, ismertetve a kvalitatív kutatással kapcsolatban álló területeket is (szimbolikus interakcionalizmus, fenomenológia, etnometodológia, antropológia, diskurzuselemzés, tartalomelemzés).

A kutatásban, javítóintézeti növendékek vettek részt a rákospalotai javítóintézetből 5 lány, az aszódi javítóintézetből 25 fiú. Részvételük önkéntes volt, az alkalmazott mintavételi eljárás a hólabda és az átlagtól eltérő esetek kiválasztásának módszere volt. Egyéni interjút 30 fővel (25 fiú, 5 lány) készített 3-3 alkalommal. $\mathrm{Az}$ interjúk mellett a filmterápiához kapcsolódó fókuszcsoportos beszélgetésen az átlag létszám 10-12 fő volt az Aszódi Javítóintézetből, az intézeti élet jellegzetessége miatt nem sikerült megvalósítani, hogy a csoport tagjai (egy-két fö kivételével) állandó legyen. Az volt a cél, hogy kisebb mintán mélyebb, több szempontú elemzés készüljön, ezért egy komplex kutatási modellt dolgozott ki a szerzö, melynek alapjául Stefan Busse, Christiane Ehses és Rainer Zech által kidolgozott kollektív biográfiai kutatási modell szolgált, amit önéletrajzi szövegek kvalitatív elemzésére dolgoztak ki az 1980-as évek elején. Az általa kidolgozott saját kollektív biográfiai kutatási modell kollektív, mert egy adott csoportra irányul megjelenik a társadalmi szint, biográfiai abból a szempontból, hogy a vizsgált csoportot az 
egyén szintjén igyekezett megismerni különböző kutatási módszerekkel. A modell szerkezetét ábrán mutatja be, a kutatás rendkívül komplex és szerteágazó volta miatt folyamatábrát is készített, hogy a kívülálló számára is világossá váljon a kutatás logikája a következő szempontok szerint: A kutatás mely szakaszában vagyunk? Mikor zajlott a fö szakasz? Mely intézmény volt a kutatás helyszíne? Milyen föbb feladatok készültek el az adott szakaszban?

A kutatás első fázisa az általános tájékozódást (2000-2002) között az iratanyagok elemzését, megfigyelést jelent, ebben a szakaszban az intézeti szinten mozgott, nem tért ki az egyéni szintre. A pedagógiai etnográfiai terepmunkával az egyéni szint felé orientálódott, 2002 és 2006 között a javítóintézeti fiatalok mindennapjait figyelte meg öt szakaszra bontva többféle módszerrel (szóbeli kikérdezés, résztvevő megfigyelés, interjú, fókuszcsoportos beszélgetés, müvészetterápia stb.). A pedagógiai etnográfián belül biográfiai kutatást is végzett élettörténeti interjúkat vett fel, erről részletes képet kapunk. Az interjúk tartalomelemzése során az volt a cél, hogy a rejtett összefüggéseket feltárja, a szöveg rejtett mondanivalója, összefüggésrendszere ismertté váljon. A szövegeket, tartalmakat adatokká alakította át, különféle kategóriákat alkotva: (család, családkép, gyermekkor, iskolai élmények, jövőkép). A fókuszcsoportos beszélgetésekre, a müvészetterápia foglalkozáson belül a filmterápia keretében volt lehetőség. A kiscsoportos beszélgetés témáját a filmek adták, ezzel kapcsolatban érintették a családon belüli eröszak kérdését, milyen családot szeretnének, hogyan viszonyulnak szüleikhez, mi a véleményük az iskoláról. Az elemzés során itt is kategóriákat határozott meg a témák mentén, amely összhangban volt az egyéni interjú kategóriájával. Az interjú részletekböl megismerhetjük a fiatalkorú bünelkövetök családi hátterét, a családi élet jellemzőit, nehézségeit, problémáit a családi élet müködésének zavarait, a családi élet kríziseit. Felvetődik a kérdés vajon a javító intézet tudja-e kompenzálni a korábbi szocializációs hiányokat?

Az utolsó „kutatói reflexiók a zárszó helyett” fejezetben a szerző újraértelmezi, elemzi az alkalmazott kutatási módszereket, összegzi a kutatás legfontosabb tanulságait, üzeneteit, eredményeit, a kutatás során felmerülő kérdéseket, nehézségeket. „Van-e jogom ahhoz, hogy régi sebeket felszakítsak?” utal arra, hogy „minden vizsgálat beavatkozás az érintettek életébe". Hegedüs Judit könyve nagymértékben hozzájárul ahhoz, hogy „másképp” gondolkodjunk a bünelkövető fiatalokról, hiszen a társadalom „megveti, leírja” a bünelkövető embert. Felhívja a figyelmünket arra, hogy milyen nagy a társadalom felelőssége a fiatalok kriminalizálódásában, milyen fontos szerepe van a szocializációs színtereknek (család, iskola, kortárscsoportok) életútjuk alakulásában.

Hegedűs Judit (2010): Gyermeksorsok, életutak a javítóintézeti világból. ELTE Pedagógiai és Pszichológiai Kar Pedagógiatörténeti Tanszék Közleményei 4. Sorozatszerkesztő: Németh András - Szabolcs Éva, Gondolat Kiadó, Budapest, 197 oldal 